\title{
The Effect of Low Impact Aerobic Exercise on Elderly with Dementia Cognitive Function
}

\author{
Raden Ayu Tanzila, ${ }^{1}$ Sheilla Yonaka Lindri, ${ }^{2}$ Nindia Rahma Putri ${ }^{3}$ \\ ${ }^{1}$ Department of Physiology, Faculty of Medicine, Universitas Muhammadiyah Palembang, Palembang, Indonesia, \\ ${ }^{2}$ Department of Public Health, Faculty of Medicine, Universitas Muhammadiyah Palembang, Palembang, \\ Indonesia, ${ }^{3}$ Medical Undergraduate Study Program, Faculty of Medicine, \\ Universitas Muhammadiyah Palembang, Palembang, Indonesia
}

\begin{abstract}
In the elderly population, at least $10 \%$ of those over 65 years old and $50 \%$ of those over 80 years old experience a decline in cognitive function that varies from a cognitive decline due to normal aging (age-associated memory impairment/AAMI) to a mild cognitive decline (mild cognitive impairment/MCI) and dementia. Dementia is an intellectual disorder that affects the cognitive function, memory, language function, and visuospatial function that causes irreversible changes. Many studies have stated that lifestyle management in the form of increased physical activity has a protective effect on impaired cognitive functions, inhibits cognitive function decline, and even improves cognitive function in healthy elderly people and elderly with mild cognitive impairment to dementia. Low impact aerobic exercise is a physical activity that is useful and suitable for the elderly. This study aimed to determine the effect of low impact aerobic exercise on the cognitive function of elderly people with dementia. This was a quasiexperimental study with one group pretest-posttest method that involved elderly people from Tresna Werdha Teratai Palembang, South Sumatera, Indonesia who were selected based on the inclusion and exclusion criteria $(n=38)$ from December 2018 to February 2019. Treatment provided was a low impact aerobic exercise 3 times a week for 5 weeks. Dementia was then measured before and after treatment using the Mini-mental State Examination (MMSE). The mean values of gymnastics before the treatment and after the treatment were 18.36 \pm 4.559 and 19.69 \pm 5.724 , respectively. A p value of 0.000 was obtained using the Wilcoxon test. In summary, low impact aerobic exercise influences the cognitive function of the elderly with dementia.
\end{abstract}

Key words: Cognitive function, elderly, low impact aerobic exercise

\section{Pengaruh Senam Aerobik Low Impact terhadap Fungsi Kognitif Usila dengan Demensia}

\begin{abstract}
Abstrak
Pada usia lanjut (usila), sedikitnya 10\% dari yang berusia lebih dari 65 tahun dan $50 \%$ dari yang berusia lebih dari 80 tahun mengalami penurunan fungsi kognitif yang bervariasi mulai dari penurunan kognitif karena penuaan normal (age-associate memory impairment/AAMI) serta penurunan kognitif ringan (mild cognitive impairment/ MCI) hingga demensia. Demensia adalah gangguan intelektual yang meliputi fungsi kognitif, daya ingat, bahasa, fungsi visuospasial, dan bersifat ireversibel. Banyak studi menyatakan bahwa manajemen gaya hidup berupa peningkatan aktivitas fisik mempunyai efek protektif terhadap gangguan fungsi kognitif, menghambat penurunan fungsi kognitif, serta bahkan meningkatkan fungsi kognitif pada usila yang sehat dan usila dengan penurunan fungsi kognitif ringan sampai demensia. Senam aerobik low impact merupakan aktifitas fisik yang bermanfaat dan cocok diberikan kepada usila. Penelitian ini bertujuan mengetahui pengaruh senam aerobik low impact terhadap fungsi kognitif usila dengan demensia. Penelitian ini merupakan studi quasi-experimental dengan metode pretestposttest one group yang melibatkan usila dari Tresna Werdha Teratai Palembang, Sumatera Selatan, Indonesia yang dipilih berdasar atas kriteria inklusi dan eksklusi $(n=38)$ dari bulan Desember 2018 hingga Februari 2019. Perlakuan yang diberikan berupa senam aerobik low impact 3 kali per minggu selama 5 minggu. Demensia kemudian diukur sebelum dan sesudah perlakuan menggunakan Mini-mental State Examination (MMSE). Nilai

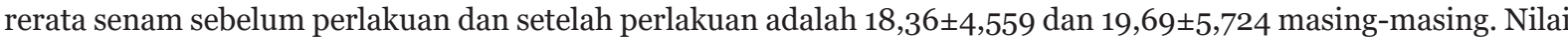
$\mathrm{p}=0,000$ didapatkan dengan menggunakan Uji Wilcoxon. Simpulan, senam aerobik low impact memengaruhi fungsi kognitif usila dengan demensia.
\end{abstract}

Kata kunci: Fungsi kognitif, senam aerobik low impact, usila

Received: 2 January 2020; Revised: 12 April 2020; Accepted: 13 April 2020; Published: 30 April 2020

Correspondence: Raden Ayu Tanzila, dr., M.Kes. Department of Physiology, Faculty of Medicine, Universitas Muhammadiyah Palembang. Jln. K.H. Balqi No.13 Ulu, Palembang 30116, South Sumatera, Indonesia. E-mail: ratanzila247@gmail.com 


\section{Introduction}

The elderly population size had increased from 14.4 million people $(7.18 \%)$ in 2000 to 16.8 million people $(7.78 \%)$ and 23.9 million people (9.77\%) in 2010. However, a decrease is seen in 2017. There were 23.66 million elderly people in Indonesia (9.03\%) and the estimated elderly population size in 2020 is 28.8 million people (11.34\%). In 2010, South Sumatra province had 454.554 senior citizens, which then increased to 582.643 in 2016. This province has an estimated annual population increase of about 60 thousand people with around $7 \%$ are elderly people. ${ }^{1}$

The increasing number of elderly people brings the consequence of increasing age-related common disorders, such as age-related cognitive function decline. Among elderly people, at least $10 \%$ of those over 65 years old and $50 \%$ of those over 80 years old experience a decline in cognitive functions that varies from the cognitive decline due to normal aging (age-associated memory impairment/AAMI) to a mild cognitive decline (mild cognitive impairment/MCI) and dementia. ${ }^{2}$

Data regarding health problems experienced by the elderly show that the biggest health problem among elderly people is degenerative diseases, including dementia. ${ }^{3}$ Dementia is a syndrome caused by a disease or brain disorder that is usually chronic and progressive in nature and affects multiple higher cognitive cortical functions, including memory, thinking ability, orientation, comprehension, arithmetic, learning ability, language, and value power (judgment). ${ }^{4,5}$ Decreased cognitive functions in the form of dementia can be inhibited by taking preventive measures.

Various literature has revealed that physical exercise provides great health benefits. Exercise does not only prevent and reduce symptoms of various diseases but also clinically plays a role in healing and recovery from diseases. ${ }^{6-8}$

One of the preventive measures that can be implemented by the elderly is aerobic exercises to increase their physical activities. ${ }^{9}$ Low impact aerobic exercise is the type of low-intensity aerobic exercise suitable for the elderly.

Previous research conducted by Cai et al. ${ }^{10}$ shows that sports interventions for 4 weeks positively affect the cognitive function in Alzheimer's patients aged over 70 years which is evident from the increase in the Mini-mental State Examination (MMSE) value from 19 before the intervention to 20 after the intervention. This shows that sports interventions positively affect cognitive functions. ${ }^{10}$ This study aimed to determine the effect of low impact aerobic exercise on the elderly with dementia.

\section{Methods}

This was a quasi-experimental pretest-posttest one group study performed from December 2018 to February 2019 on 38 elderly people in Tresna Werdha Teratai Palembang, which is a nursing home for the Elderly in South Sumatera, Indonesia. Participants were recruited using the total sampling method in which all elderly people who met the inclusion criteria were included. The inclusion criteria used were elderly with dementia (MMSE $\leq 24)$, able to walk without any assistive device, minimum education of elementary school, willing to voluntarily participate in the study, as evident by signing the informed consent, to do routine gymnastic exercise 3 times a week for 5 weeks at Tresna Werdha Teratai Palembang.

The low impact aerobic gymnastic program assigned to the participants consisted of warming up (10 minutes), core exercise comprising various aerobic movements (30 minutes), and cooling down (10 minutes). Data were collected before and after the low impact aerobic exercise using the MMSE to assess the cognitive function. The MMSE is a widely used test for assessing elderly cognitive function. It includes tests of orientation, attention, memory, language, and visuospatial skills. The MMSE test includes simple questions and problems in some areas: time and place of test, repeating list of words, arithmetic including serial sevens, language use and comprehension, and basic motor skill. ${ }^{11}$

Data collected were processed by using a computer program system and then analyzed univariately to understand the average cognitive function of the elderly before and after gymnastics. Bivariate analyses using paired t test and Wilcoxon test as the alternative test were used to determine the effects of low impact aerobic exercise on the cognitive function of elderly people with dementia. Results were considered significant if $\mathrm{p}$ value $<0.05$.

This study has received ethical clearance from the Research Ethics Committee of the Bioethics, Humanities, and Islamic Medicine Unit (UBHKI) of the Faculty of Medicine, Universitas Muhammadiyah Palembang with letter number: 
oo6/EC/UBHKI/FK-UMP/X/2018.

\section{Results}

Table 1 showed cognitive function mean values before and after low impact gymnastics. It is apparent that the 38 respondents presented different mini-mental status (MMSE) scores between before $(18.36 \pm 4.559$, p value $=0.003)$ and after the low impact aerobic physical activity $(19.69 \pm 5.724, \mathrm{p}$ value $=0.002)$. This proved that the data gained did not follow the normal distribution.

The Wilcoxon test on data from 38 respondents presented a $\mathrm{p}$ value of $0.000(\mathrm{p}<0.05)$, meaning that the low impact aerobic exercise in this study affected the cognitive function of the elderly with dementia (Table 2).

\section{Discussion}

This study found that the routine low impact aerobic exercises increased the cognitive functions of elderly people with dementia ( $p$ value $=0.000$ ). This is in line with the finding of a study conducted by Rohana ${ }^{12}$ stating the influence of aerobic physical activities on cognitive function in the elderly with dementia. Besides, another study conducted by Yolanda and Fatmawati ${ }^{13}$ suggested a significant difference in the cognitive function of the elderly before and after doing aerobic physical activities in the form of brain vitality exercises. Hence, it can be stated aerobic physical activities indeed influence the cognitive function of the elderly with dementia.

In contrast, several studies have suggested that there is no increase in the cognitive function of the elderly after doing exercises. One study on 141 women and 45 men who did exercises for 4 months obtained a p value of 0.11 , which means that the exercise does not affect the cognitive functions of these elderly people. This may relate to the severity of dementia condition suffered

Table 1 Cognitive Function Mean Values before and after Low Impact Gymnastics

\begin{tabular}{lcc}
\hline Gymnastics & $\begin{array}{c}\text { Mean } \pm \text { SD } \\
(\mathbf{n}=\mathbf{3 8})\end{array}$ & p Value* \\
\hline Before & $18.36 \pm 4.559$ & 0.003 \\
After & $19.69 \pm 5.724$ & 0.002 \\
\hline
\end{tabular}

by the participants, as well as the duration and frequency of the exercise. It is commonly understood that $85 \%$ of the lack of effect on cognitive function is caused by the type of dementia that is a post-stroke vascular dementia with lesions in several parts of the brain lobes. ${ }^{14,15}$

A study in Ngesrep village shows that routine physical exercises result in a significant influence on the cognitive performance of older people who visited the posyandu (integrated health post) routinely. ${ }^{16} \mathrm{~A}$ meta-analysis involving 29 randomized controlled trials of healthy elderly people without dementia found that aerobic exercises improved cognitive functions including memory, attention, speed of information processing, and executive functions. ${ }^{17}$

A beneficial effect on the cognitive functions of the elderly with dementia has been linked to physical exercise activities. ${ }^{18}$ Aerobic exercise influences the Papez circuit limbic system, especially at the relay station as neural impulses received at this station are influenced by several neurotransmitters, like norepinephrine, dopamine, and acetylcholine. The aerobic physical activities can activate the hypothalamus to synthesize corticotropin-releasing factors (CRFs), which will influence the release of neurotransmitters like acetylcholine, serotonin, dopamine, and norepinephrine. This, in turn, will affect the impulse of the Papez circuit. The impulse will travel through the arch of the fornix to the corpus of mamillare and then will be delivered to the anterior nucleus of the thalamus, which will project it into the cinguli girus thereby increasing nerve growth factor (NGF) and brain-derived neurotrophic factor (BDNF) in the cinguli gyrus, hippocampus, and dentate girus. Furthermore, the CRF synthesized by the hypothalamus will be sent to the pituitary to synthesize adrenocorticotropic hormone (ACTH) and this ACTH will later be sent to the adrenal gland to synthesize the cortisol hormone that increases the memory consolidation..$^{19-21}$ Aerobic physical activities change the blood flow; thereby

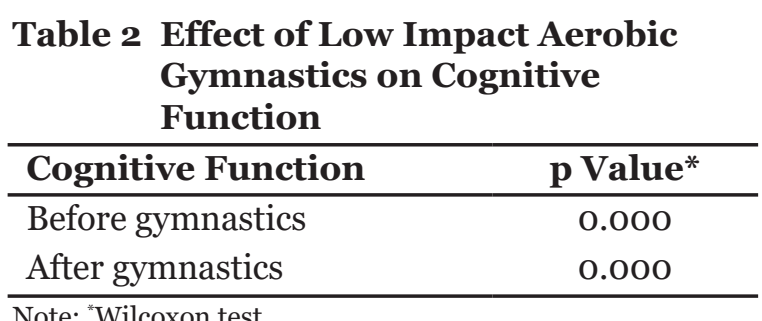


increasing the intake of oxygen and glucose, as well as lipid metabolism, to the brain that reduces the process of ischemia and damages to the microvascular (reperfusion injury). It also reduces the production of reactive oxygen species (ROS) which are destructive and tends to form free radicals. Hence, the NGF and BDNF of the nerve cells increase and they provide a protective effect for cell neurons as well as reducing the amyloid build-up on neurons that can cause an increase in cognitive abilities in elderly people..$^{22,23}$

Physical activities also improve the physical capacity of patients with dementia. Multiple exercises that are combined into physical activity for patients with dementia have shown to have the largest effect. Therefore, a physical activity program that includes various activities is recommended to be included in the treatment for elderly patients with dementia. ${ }^{24,25}$ It is expected that the findings of this study will be able to provide inputs when considering treatment for people with dementia, especially in taking the advantage of the low impact exercise as an alternative approach to improve memory among elderly people.

\section{Conclusion}

Low impact aerobic exercises improve the cognitive functions of elderly people with dementia in Tresna Werdha Teratai Palembang, South Sumatera, Indonesia.

\section{Conflict of Interest}

There is no conflict of interest at all authors.

\section{References}

1. Badan Pusat Statistik. Statistik penduduk lanjut usia 2017. Jakarta: Badan Pusat Statistik; 2018 [cited 2019 May 20]. Available from: https://www.bps.go.id/publication/ 2018/04/13/7a130a22aa29cc8219c5d153/ statistik-penduduk-lanjut-usia-2017.html.

2. Masruroh. Efek aktivitas berjalan kaki terstruktur dalam memelihara fungsi kognitif pada usia lanjut: uji klinis acak tersamar tunggal [thesis]. Jakarta: Universitas Indonesia; 2014 [cited 2019 May 3]. Available from: http://lib.ui.ac. id/file?file $=$ digital $/ 2016-3 / 20405274-S P-$ Masruroh.pdf.

3. Pusat Data dan Informasi, Kementerian
Kesehatan Republik Indonesia. Situasi lanjut usia (lansia) di Indonesia [Internet]. 2016 May [cited 2019 May 5]. Available from: https://pusdatin.kemkes.go.id/resources/ download/pusdatin/infodatin/Infodatinlansia-2016.pdf.

4. Mandolesi L, Polverino A, Montuori S, Foti F, Ferraioli G, Sorrentino P, et al. Effects of physical exercise on cognitive functioning and wellbeing: biological and psychological benefits. Front Psychol. 2018;9:509.

5. Maslim R. Buku saku diagnosis gangguan jiwa: rujukan ringkas dari PPDGJ-III dan DSM-5. Jakarta: Bagian Ilmu Kedokteran Jiwa FK-Unika Atmajaya; 2013.

6. Powers SK, Howley ET. Exercise physiology: theory and application to fitness and performance. $10^{\text {th }}$ Edition. New York: McGraw-Hill Education; 2018.

7. Wahyuni NPDS. Sehat dan bahagia dengan senam bugar lansia. J Penjakora. 2015;3(1):66-77.

8. Sauliyusta M, Rekawati E. Aktivitas fisik memengaruhi fungsi kognitif lansia. JKI. 2016;19(2):71-7.

9. Tulak TG, Umar M. Pengaruh senam lansia terhadap penurunan tekanan darah lansia penderita hipertensi di Puskesmas Wara Palopo. Perspektif. 2017;2(1):169-72.

10. Cai H, Li G, Hua S, Liu Y, Chen L. Effect of exercise on cognitive function in chronic disease patients: a meta-analysis and systematic review of randomized controlled trials. Clin Interv Aging. 2017;12:773-83.

11. Schweizer TA, Al-Khindi T, Macdonald RL. Mini-Mental State Examination versus Montreal Cognitive Assessment: rapid assessment tools for cognitive and functional outcome after aneurysmal subarachnoid hemorrhage. J Neurol Sci. 2012;316(12):137-40.

12. Rohana S. Senam vitalisasi otak lebih meningkatkan fungsi kognitif kelompok lansia daripada senam lansia di Balai Perlindungan Sosial Propinsi Banten. Fisioterapi. 2011;11(1):15-35.

13. Yolanda J, Fatmawati V. Perbedaan pengaruh senam vitalisasi otak dan senam lansia terhadap peningkatan fungsi kognitif pada lansia [undergraduate thesis]. Yogyakarta: Universitas 'Aisyiyah; 2017 [cited 2019 April 30]. Available from: http://digilib. unisayogya.ac.id/2858/1/NASKAH\%2O PUBLIKASI\%2OPDF.pdf. 
14. Wan M, Wong RY. Benefits of exercise in the elderly. CGS J CME, 2014;4(1):5-8.

15. Kenney WL, Wilmore JH, Costill DL. Physiology of sport and exercise. $5^{\text {th }}$ Edition. Champaign: Human Kinetics; 2012.

16. Kusumowardani A, Wahyuni ES. Pengaruh latihan fisik terhadap kemampuan kognitif lansia di Desa Ngesrep Kecamatan Ngemplak Kabupaten Boyolali. Interest. 2017;6(2):16878.

17. Teri L, Logsdon RG, McCurry SM. Exercise interventions for dementia and cognitive impairment: the Seattle Protocols. J Nutr Health Aging. 2008;12(6):391-4.

18. Setiawan RA. Pengaruh senam otak dengan fungsi kognitif lansia demensia di Panti Wredha Dharma Bakti Kasih Surakarta [undergraduate thesis]. Surakarta: STIKes Kusuma Husada Surakarta; 2014 [cited 2019 May 6]. Available from: http://digilib.ukh. ac.id/files/disk1/12/o1-gdl-rochmadagu566-1-skripsi_-n.pdf.

19. Hötting K, Schickert N, Kaiser J, Röder B, Schmidt-Kassow M. The effects of acute physical exercise on memory, peripheral BDNF, and cortisol in young adults. Neural Plast. 2016;2016:6860573.

20. Rodwell VW, Bender DA, Botham KM, Kennelly PJ, Weil PA. Biokimia Harper. $30^{\text {th }}$ Edition. Jakarta: EGC; 2017.

21. Baehr M, Frotscher M. Diagnosis topik neurologi Duus: anatomi, fisiologi, tanda, gejala. $5^{\text {th }}$ Edition. Jakarta: EGC; 2017.

22. Bherer L, Erickson KI, Liu-Ambrose T. A review of the effects of physical activity and exercise on cognitive and brain functions in older adults. J Aging Res. 2013;2013:657508.

23. Myers JS. Factors associated with changing cognitive function in older adults: implications for nursing rehabilitation. Rehabil Nurs. 2008;33(3):117-23.

24. Sherwood L. Fisiologi manusia: dari sel ke sistem. $9^{\text {th }}$ Edition. Jakarta: EGC; 2018.

25. Lee HS, Park SW, Park YJ. Effects of physical activity programs on the improvement of dementia symptom: a meta-analysis. Biomed Res Int. 2016;2016:2920146. 